\title{
Damping-off of Coastal Hogfennel Caused by Rhizoctonia solani AG-4
}

*Corresponding author

Tel: $+82-31-292-7848$

Fax: +82-31-292-7849

E-mail:wgkim5121@naver.com

ORCID

https://orcid.org/0000-0003-1813-4480

\author{
Youn-Gi Moon ${ }^{1}$, Se-Won Kim ${ }^{1}$, Hyun-Taek Seo ${ }^{1}$, and Wan-Gyu Kim ${ }^{2 *}$ \\ 'Wild Vegetable Research Institute, Gangwondo Agricultural Research and Extension Services, \\ Pyeongchang 25300, Korea \\ ${ }^{2}$ Global Agro-Consulting Corporation, Suwon 16614, Korea
}

Received October 26, 2020

Revised November 26, 2020

Accepted January 22, 2021

\begin{abstract}
Damping-off symptoms were frequently observed on young plants of coastal hogfennel (Peucedanum japonicum) grown in a farmer's vinyl greenhouse located in Goseong, Gangwon Province, Korea during a disease survey in June 2019. Incidence of the diseased plants was $50-70 \%$ in the vinyl greenhouse investigated during the disease survey. Eight isolates of Rhizoctonia sp. were obtained from the diseased plants. All the isolates were identified as Rhizoctonia solani AG-4 based on the morphological characteristics and anastomosis test. Three isolates of $R$. solani AG-4 were tested for pathogenicity on coastal hogfennel by artificial inoculation. All the tested isolates induced damping-off symptoms on the inoculated plants. The symptoms were similar to those observed in the farmer's vinyl greenhouse investigated. This is the first report of R. solani AG-4 causing damping-off in coastal hogfennel.
\end{abstract}

Keywords: Anastomosis group, Coastal hogfennel, Damping-off, Pathogenicity, Rhizoctonia solani AG-4
Coastal hogfennel (Peucedanum japonicum) is known to be distributed in east and southeast Asia. The plant originated from the wild has been grown in Korea as a vegetable. Korean farmers mainly grow the plant in vinyl greenhouses. Damping-off symptoms were frequently observed on young plants of coastal hogfennel grown in a farmer's vinyl greenhouse located in Goseong, Gangwon Province, Korea during a disease survey in June 2019. The symptoms began on the soil surface parts of the plants. The infected plant parts receded and were thin, discolored, and rotten. Diseased plants fell down and later dried up (Fig. 1A, B). One hundred plants in the vinyl greenhouse were investigated in three replicates. Incidence of the disease on the plants was $50-70 \%$ in the vinyl greenhouse investigated during the disease survey.

Rhizoctonia sp. was frequently isolated from the diseased

Research in Plant Disease

pISSN 1598-2262, elSSN 2233-9191

www.online-rpd.org plants of coastal hogfennel. Eight isolates of Rhizoctonia sp. were obtained from petioles of the diseased plants. All the isolates were identified as Rhizoctonia solani based on the morphological characteristics according to the descriptions of previous studies (Parmeter and Whitney, 1970; Sneh et al., 1991).

The isolates were tested to classify anastomosis groups using tester isolates of $R$. solani as previously conducted (Kim et al., 1994). The tester isolates of $R$. solani, AG-1 (KACC 40101), AG-2-1 (KACC 40119), AG-2-2 (40125), AG-3 (KACC 40138), AG-4 (KACC 40139), and AG-5 (KACC 40146) were obtained from the Agricultural Microbiology Division, National Institute of Agricultural Sciences in Korea. All the tested isolates were classified as $R$. solani AG-4. Anastomosis reactions between the tested isolate and the tester isolate of $R$. solani AG-4 were shown in Fig. 2A. Mycelia of the isolates cultured on potato dextrose agar (PDA) were whitish light brown (Fig. 2B). Sclerotia were absent or rarely formed on the medium.

Three isolates of $R$. solani AG-4 were tested for pathogenicity on coastal hogfennel by artificial inoculation. Mycelial 


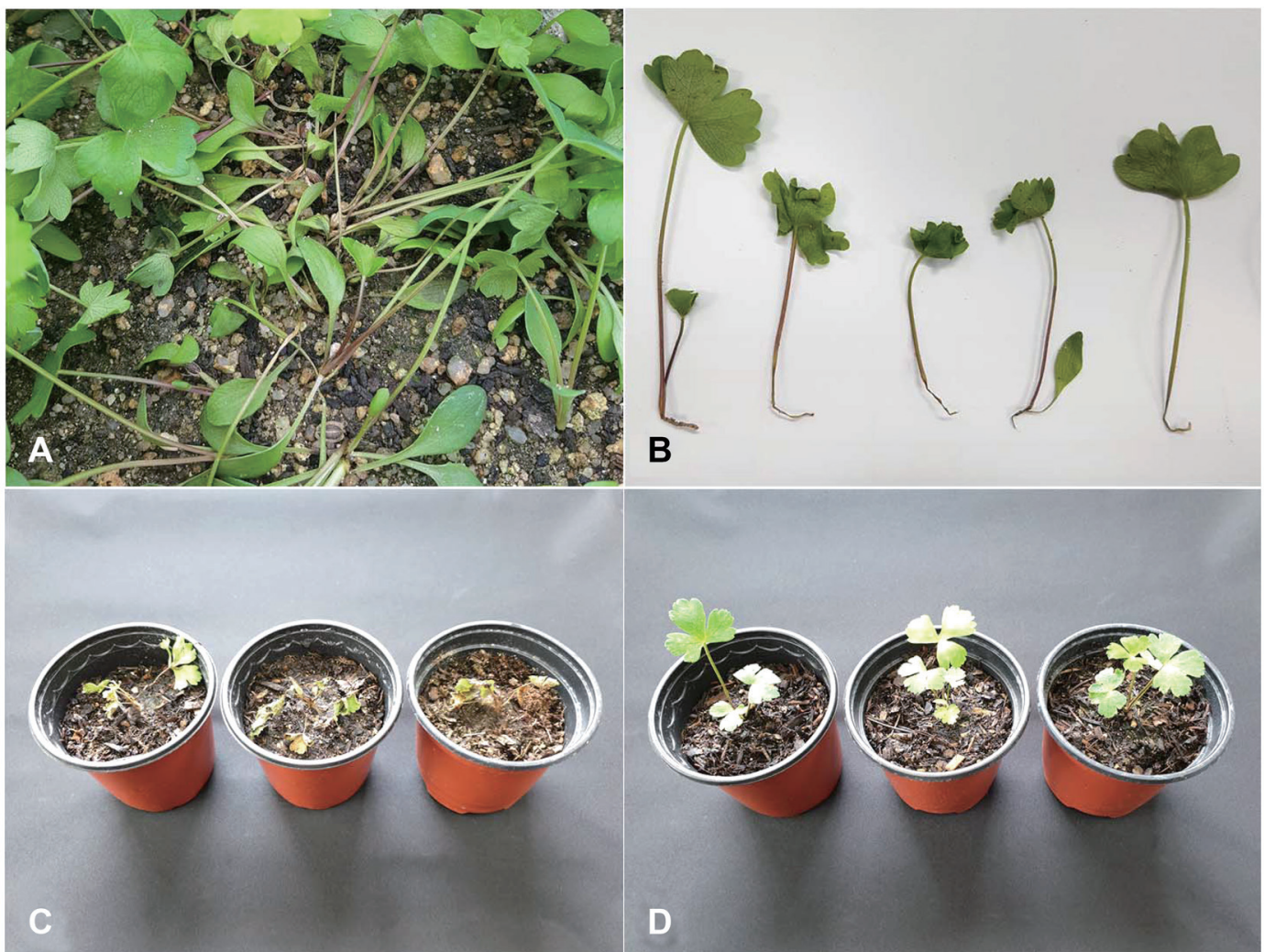

Fig. 1. Damping-off symptoms of coastal hogfennel plants. (A, B) Symptoms observed in the vinyl greenhouse investigated. (C) Symptoms induced by artificial inoculation tests with Rhizoctonia solani AG-4 isolates. (D) Non-inoculated plants (control).

disks of $6 \mathrm{~mm}$ in diameter cut from the margins of actively growing cultures of each isolate on PDA were placed on plant bases of 62-day-old coastal hogfennel plants grown in circular plastic pots $(9 \mathrm{~cm}$ in height, $10 \mathrm{~cm}$ in upper diameter, and $7 \mathrm{~cm}$ in lower diameter) in the vinyl greenhouse. Inoculated plant pots were placed in plastic boxes $(60 \times 43 \times 33 \mathrm{~cm})$ with $100 \%$ relative humidity at room temperature $\left(24-26^{\circ} \mathrm{C}\right)$ for two days. Then, the inoculated plant pots were taken out of the boxes and kept indoors. Virulence of the isolates was rated based on the degree of damping-off symptoms induced five days after inoculation. The inoculation test was performed in three replicates.

All the tested isolates of $R$. solani AG-4 induced dampingoff symptoms on the inoculated plants (Fig. 1C). There was no symptom on the control plants (Fig. 1D). The symptoms on the plants induced by artificial inoculation were similar

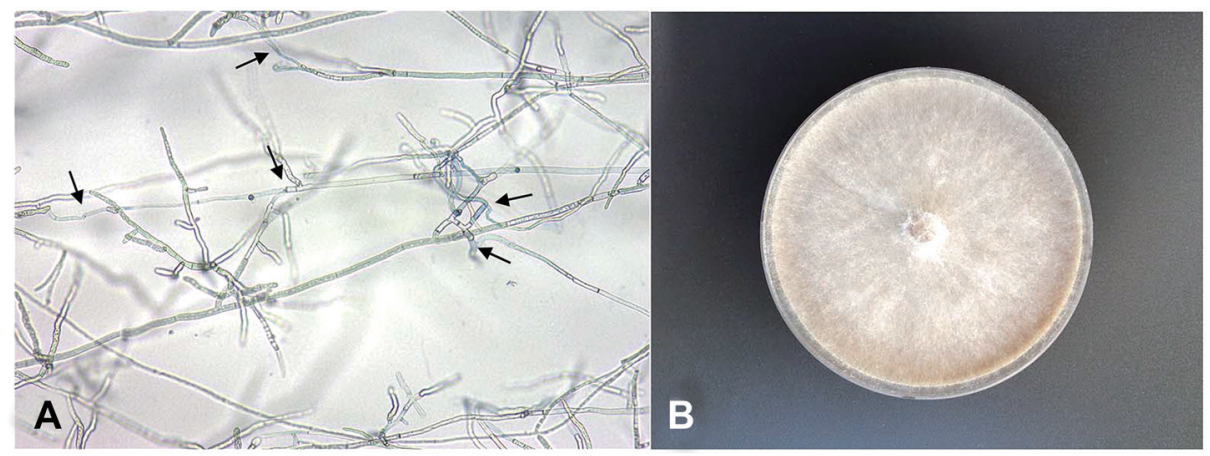

Fig. 2. Anastomosis test of Rhizoctonia solani isolate from coastal hogfennel and cultural appearance of the isolate. (A) Anastomosis reactions between the tested isolate (left) and the tester isolate (right) of $R$. solani AG-4. The arrows indicate points of hyphal anastomosis. (B) A colony of R. solani AG-4 isolate grown on potato dextrose agar at $25^{\circ} \mathrm{C}$ for 10 days. 
to those observed in the vinyl greenhouse investigated. The isolates which induced symptoms on the plants were reisolated from the symptoms.

R. solani is reported to cause damping-off in many crops (Farr and Rossman, 2020; Kim et al., 1995). It has been reported that $R$. solani AG-1(IB) and $R$. solani AG-2-2(IIIB) cause leaf blight and root rot of coastal hogfennel, respectively (Kim, 1996; Kim et al., 1995). However, there has been no report on damping-off of coastal hogfennel caused by $R$. solani AG-4. This is the first report of $R$. solani AG-4 causing damping-off in coastal hogfennel.

\section{Conflicts of Interest}

No potential conflict of interest relevant to this article was reported.

\section{Acknowledgments}

This study was supported by a research grant (PJ014507012020) from Rural Development Administration, Korea and a project
(No. 117038-03) from Korea Institute of Planning and Evaluation for Technology in Food, Agriculture, Forestry.

\section{References}

Farr, D. F. and Rossman A, Y. 2020. Fungal Databases, U.S. National fungus Collections, ARS, USDA. URL https://nt.ars-grin.gov/fungaldatabases/ [25 October 2020].

Kim, W. G. 1996. Pathogenicity of anastomosis groups and cultural types of Rhizoctonia solani on crops. Korean J. Plant Pathol. 12: 21-32.

Kim, W. G., Cho, W. D. and Lee, Y. H. 1994. Anastomosis groups and cultural characteristics of Rhizoctonia solani isolates from crops in Korea. Korean J. Mycol. 22:309-324.

Kim, W. G., Cho, W. D. and Ryu, H. Y. 1995. Diagnosis and Control of Rhizoctonia Diseases on Crops. National Agricultural Science and Technology Institute, Suwon, Korea. 167 pp. (In Korean)

Parmeter, J. R. Jr. and Whitney, H. S. 1970. Taxonomy and nomenclature of the imperfect state. In: Rhizoctonia solani, Biology and Pathology, ed. by J. R. Jr. Parmeter, pp. 7-19. University of California Press, Berkeley, CA, USA.

Sneh, B., Burpee, L. and Ogoshi, A. 1991. Identification of Rhizoctonia Species. APS Press, The American Phytopathological Society, St. Paul, MN, USA. 133 pp. 